\title{
Preparation of Ceramic Composite Membranes for Protein Separation
}

\author{
I. Erdem, M. Çiftçioğlu, Ş. Harsa \\ İzmir Institute of Technology, Biotechnology Graduate Program, \\ Gülbahçe Köyü, Urla, İzmir, Turkey
}

Keywords: ceramic membrane, ultrafiltration, protein, whey, alumina, zirconia

\begin{abstract}
Ceramic supports were prepared from fine alumina and zirconia powders by dry-pressing and slip-casting. These supports were heat treated in the $1100^{\circ}-1200^{\circ} \mathrm{C}$ temperature range and dipcoated with ceramic sols prepared from alkoxides by using sol-gel methods. The average sol particle sizes were measured as 3-7 nm for zirconia and 30-40 nm for alumina by laser scattering technique. The optimum heat treatment temperature range was determined as $500^{\circ}-600^{\circ} \mathrm{C}$ for dipcoated membranes by using TGA (thermo gravimetric analysis) results. The microstructure of the ceramic composite membranes was investigated by SEM (Scanning electron microscope).

The clean water permeability (CWP) of the membranes was tested by using deionized water in a filtration set-up. Separation experiments were performed with bovine serum albumin (BSA, Stokes diameter: $7 \mathrm{~nm}$ ) solution and whey to determine the protein separation capacity of the composite membranes. The CWP of the dry pressed alumina supports heat treated at $1100^{\circ} \mathrm{C}$ was found to be higher than the permeability of the slip-casted zirconia supports heat treated at $1200^{\circ} \mathrm{C}$. The protein retention of the slip-casted zirconia support was determined as $60 \%$ by using UV-Vis spectrophotometer (Abs. at $280 \mathrm{~nm}$ ). A protein retention value of $96 \%$ was achieved for whey after the modification of the support with dip-coating. The permeate flux was $40 \mathrm{~L} / \mathrm{m}^{2}$ hour for drypressed alumina support dip-coated with zirconia sol calcined at $500^{\circ} \mathrm{C}$.
\end{abstract}

\section{Introduction}

Protein concentrates with high nutritive value are needed for nutrition of infants and sportsmen. Such protein concentrates may be produced from whey which is a by-product of cheese manufacturing by using ultrafiltration (UF). Whey is a complex biological liquid, with a BOD (Biological Oxygen Demand) value between $32-60 \mathrm{~g} / \mathrm{L}$, containing proteins, carbohydrate (lactose) and minerals [1]. UF separates protein from whey while leaving lactose and minerals in permeate. Ceramic or polymeric membranes can be used for ultrafiltration. The former possess desirable properties for industrial separation and concentration processes where extreme conditions of heat, $\mathrm{pH}$ and ionic strength are present. Ceramic composite membranes are economical choices when compared with polymeric membranes due to their higher chemical, physical, thermal and microbiological stability which allow longer service life [1].

Steenkamp et al. [2] prepared tubular ceramic membranes from two alumina powders (AKP-15 and AKP-30, Sumitomo Chemical Co. Ltd., Japan) with mean particle diameters 0.62 and $0.40 \mu \mathrm{m}$. They reported that the strength of the tubes they prepared increased with the increase in sintering temperature and decreasing particle size. The clean water permeability (CWP) values of the membranes were in the $5-50 \mathrm{~L} / \mathrm{m}^{2}$ hour bar range. Avc1 et al. [3] prepared alumina supports by using Alcoa A-16 SG and Seydişehir Alumina powders. The supports prepared from spray-dried Seydişehir Alumina powders with a coarser microstructure were found to have the highest CWP values. Research on filtration of whey with commercial ceramic membranes mostly focus on fouling problems [4]. In this study, ceramic composite membranes made of alumina and zirconia were prepared and used for protein separation from model protein solutions and whey. 


\section{Experimental}

Materials. Alumina (AKP-50, Sumitomo Chemical Co., Japan) and zirconia (TZ-3Y, Tosoh Corp., Japan) ceramic powders, polyvinyl alcohol (PVA, molecular weight; 9,000-10,000), polyacrylic acid (PAA), and ammonium hydroxide were used for the preparation of ceramic disc supports. Zirconium propoxide (70\% in alcohol), aluminium iso propoxide, propanol, nitric acid and deionized water were used for preparing ceramic sols. Bovine serum albumin (BSA, Fraction V, Sigma Chemical Co., USA) solution and whey obtained from a local cheese manufacturer (PINAR SÜT A.Ş., İzmir, Turkey) were used for testing the separation efficiency of the membranes.

Methods. Ceramic disc supports (45 $\mathrm{mm}$ in diameter) were prepared by either cold pressing of $3 \%$ PVA added ceramic powders or by slip-casting using ceramic powder suspensions stabilized by PAA and ammonium hydroxide. The suspension was kept in ultrasonic bath for 3 hours before casting into cylindrical dies. The green bodies were heat treated in the $1100^{\circ}-1200^{\circ} \mathrm{C}$ temperature range. After the heat treatment the microstructure of the supports were investigated by using SEM(Philips XL30 SFEG).

Ceramic sols were prepared from zirconium propoxide and aluminium isopropoxide . The molar ratios for zirconium propoxide / propanol / nitric acid / water were 1 / 13.31 / 0.826 / 2 for zirconia and aluminium isopropoxide / nitric acid / water as 1 / 0.005 / 0.00125 for alumina. The particle size distributions of the sols were determined by using Zetasizer 3000HSA. These sols were used for dip-coating with or without dilutions. TGA was used to determine the optimum heat treatment temperature in order to get a thermally stable top layer. The phase structure of dried and heat treated unsupported membranes were investigated by using XRD (Philips X'PERT PRO). The composite membranes consisting of a support and a thin membrane layer were investigated with SEM.

The separation efficiency and clean water permeability (CWP) of the membranes were tested by using a specially designed filtration system, consisting of a piston pump with frequency controller, flowmeter, pressure gauges, needle valves, feed tank and membrane holder. The temperature of the feed was controlled by using an immersion circulator placed on the feed tank. The feed flow was controlled by changing the frequency of the pump and monitored by a flowmeter as litre per minute (LPM). The permeate flux was calculated by measuring the time required for filling a $5 \mathrm{~mL}$ tube with permeate. The transmembrane pressure (TMP) was controlled by the needle valve controlling the retentate flow and monitored by pressure gauges (in bar). The feed stream was either BSA solution $(2.5 \mathrm{~g} / \mathrm{L})$ or whey. The protein content in the permeate and retentate streams were determined by using a spectrophotometric method (Lowry Method) and the protein retention values were calculated by using the following equation,

$$
\mathrm{PR} \%=100 \mathrm{X}\left[1-\left(\mathrm{C}_{\mathrm{p}} / \mathrm{C}_{\mathrm{r}}\right)\right] .
$$

where $C_{p}$ and $C_{r}$ are protein concentrations in permeate and retentate. The filtration experiments were performed at TMP $=5$ bar, feed flux $=5 \mathrm{LPM}, \mathrm{T}_{\text {feed }}=40^{\circ} \mathrm{C}$ if not mentioned otherwise.

\section{Results and Discussion}

Both sols have uniform particle size distributions with average particle sizes of $5 \mathrm{~nm}$ and $30 \mathrm{~nm}$ for zirconia and alumina, respectively (Fig. 1). These homogenous sols would give a homogenous porous structure with adjustable pore sizes under well-controlled conditions. The TGA results indicated that heat treatment over $500^{\circ} \mathrm{C}$ was sufficient to obtain a thermally stable structure from both sols. 
The SEM micrograph of the dry-pressed alumina support heat treated at $1100^{\circ} \mathrm{C}$ is given in Fig.2. The support has a homogenous pore structure formed by submicron particles. Fig. 3 shows the SEM micrograph of a dip-coated zirconia support. The dip-coated zirconia formed a porous semitransparent thin layer over the zirconia support.

The clean water permeabilities (CWP) of two ceramic supports (slip-casted zirconia heat-treated at $1200^{\circ} \mathrm{C}$ and dry-pressed alumina heat-treated at $1100^{\circ} \mathrm{C}$ ) are given in Fig. 4. The CWP values for the alumina support were higher than the CWP values for the zirconia support. This may be due to the heat treatment performed at higher temperature. The CWP values of dry-pressed alumina for transmembrane pressure values up to 5 bar is given since at higher pressures the supports failed. Steenkamp et al. [2] reported that ceramic supports with a mean particle diameter of $0.40 \mu \mathrm{m}$ were mechanically stronger than those with $0.62 \mu \mathrm{m}$ after the same heat treatment. The higher mechanical strength of slip-casted zirconia support is most likely due to the microstructure obtained after heat treatment performed at $1200^{\circ} \mathrm{C}$.
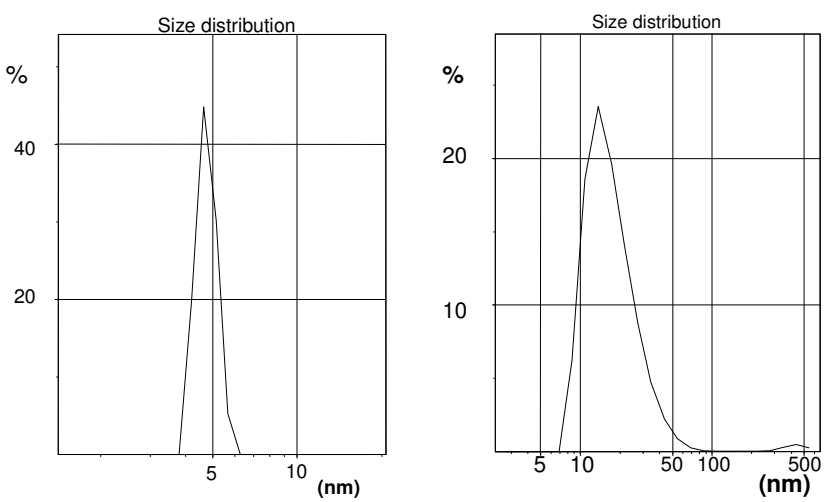

Figure 1. Particle size distributions of zirconia $($ mean $=5 \mathrm{~nm})$ and alumina sols $($ mean $=30 \mathrm{~nm})$.

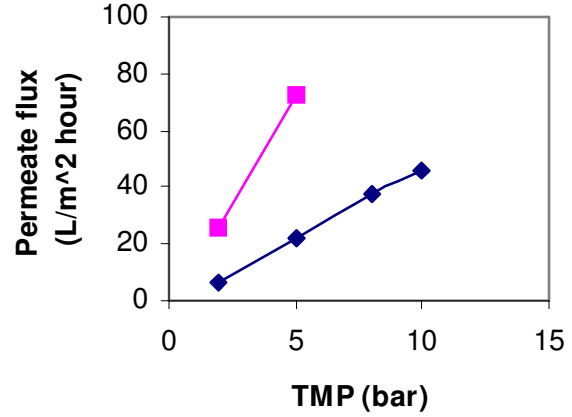

Figure 4. Clean water permeabilities of ceramic supports (alumina $1100^{\circ} \mathrm{C}: \bullet$, zirconia $1200^{\circ} \mathrm{C}:-$ ).

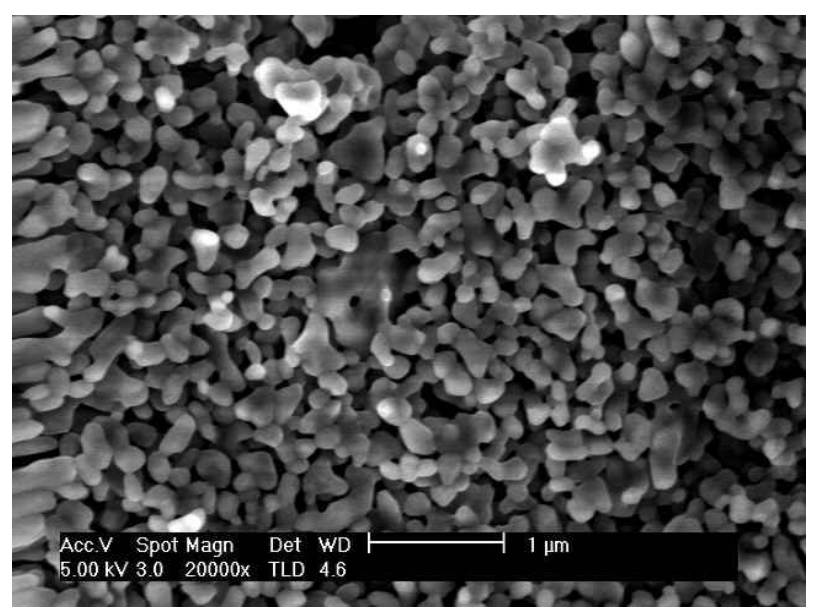

Figure 2. The SEM micrograph of drypressed alumina support.

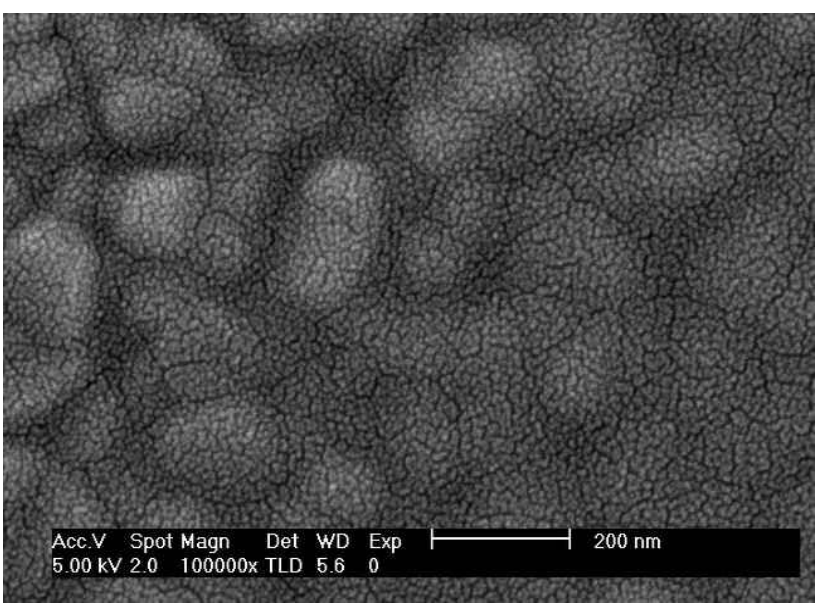

Figure 3. The SEM micrographs of zirconia sol coated zirconia support . 
Even with the slip-casted zirconia support $60 \%$ protein retention (PR\%) without any modification was obtained. No significant increase in PR\% was determined when it was modified by dip-coating with zirconia sol (60-65\%) but when it was dip-coated with diluted (1:4) sol the PR\% value increased to $85-95 \%$ (The calcination temperature for zirconia sol was $500^{\circ} \mathrm{C}$ ). Dip-coating with diluted alumina sol (1:3) increased the PR\% value to $70 \%$ if the calcination temperature was $500^{\circ} \mathrm{C}$ and $95-90 \%$ when it was $600^{\circ} \mathrm{C}$ (Fig.5).

Since the dry-pressed alumina support partially sintered at $1100^{\circ} \mathrm{C}$ was found to have a higher permeate flux (CWP) than zirconia support, former was chosen for whey protein separation experiments. The PR\% values for unclarified whey were over $95 \%$ and the permeate flux was about $40 \mathrm{~L} / \mathrm{m}^{2}$ hour for dry-pressed alumina support dip-coated with diluted zirconia sol calcined at $500^{\circ} \mathrm{C}$ as seen in Fig.5.

The protein retention values of the dip-coated membranes were found to be high (over 95\%), but the flux values should be enhanced by using coarser powders for support preparation. The porous structure formed by zirconia nanoparticles promises new opportunities for different applications.
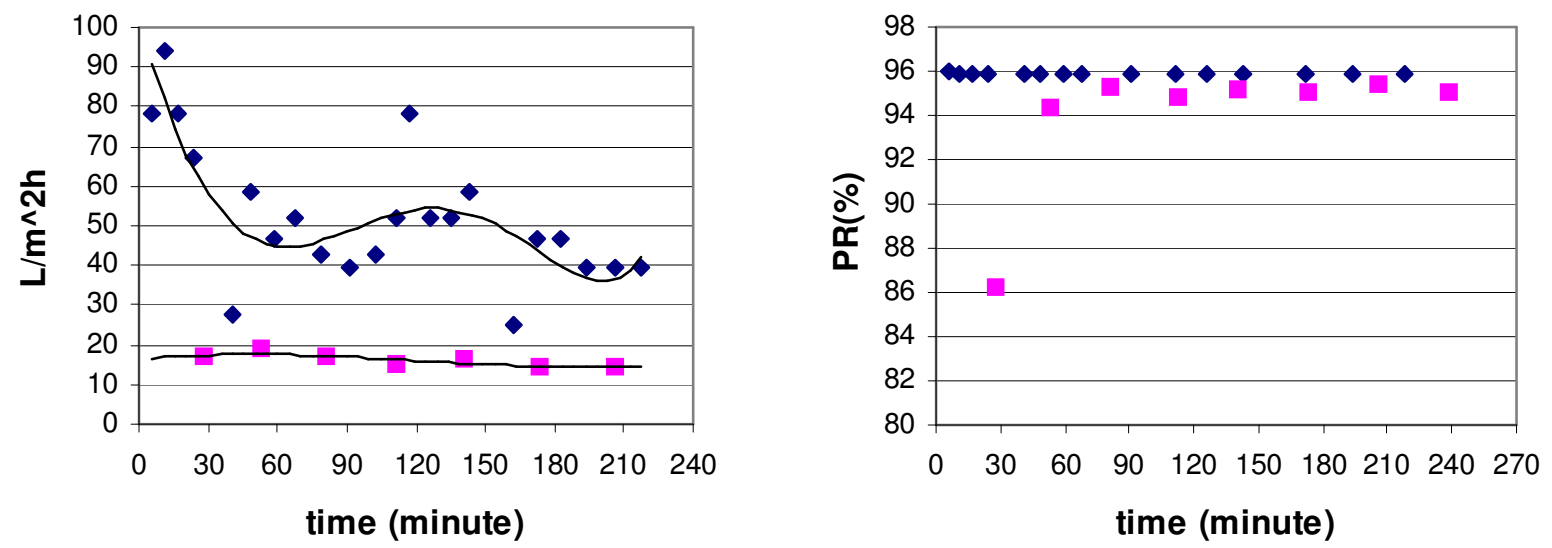

Figure 5. The permeate flux $\left(\mathrm{L} / \mathrm{m}^{2} \mathrm{~h}\right)$ and protein retention values for zirconia coated $\left(500^{\circ} \mathrm{C}\right)$ alumina support $(\bullet)$ and alumina coated $\left(600^{\circ} \mathrm{C}\right)$ zirconia support $(\bullet)$.

\section{Summary}

Alumina and zirconia composite membranes for protein separation were produced consisting of a support and a thin membrane layer formed by dip-coating. Alumina and zirconia sols were prepared with sharp particle size distributions and were dip-coated on dry-pressed or slip-casted ceramic supports. PR\% values over $90 \%$ were achieved with these membranes. Separation of whey proteins were achieved with a PR\% value of $96 \%$ and a permeate flux of about $40 \mathrm{~L} / \mathrm{m}^{2}$ hour with a drypressed alumina support heat treated at $1100^{\circ} \mathrm{C}$ which was dip-coated with a diluted zirconia sol heat treated at $500^{\circ} \mathrm{C}$.

\section{References}

[1] Cheryan, M., Ultrafiltration and Microfiltration Handbook, (Technomic Publishing Company, Switzerland, 1998)

[2] Avcı, G. G., Misırlı, Z., Günay, V., Ceramics International, Vol. 22 (1995), p. 23

[3] Steenkamp, G. C., Neomagus, H. W. J. P., Krieg, H. M., Keizer, K., Separation and Purification Technology, Vol. 25 (2001), p.407

[4] Daufin, G., Michel, F., Labbe, J.-P., Quemerais, A., Grangeon, A., Journal of Dairy Research, Vol. 60 (1993), p. 79. 


\section{Euro Ceramics VIII}

10.4028/www.scientific.net/KEM.264-268

\section{Preparation of Ceramic Composite Membranes for Protein Separation}

10.4028/www.scientific.net/KEM.264-268.2251

\section{DOI References}

[3] Steenkamp, G. C., Neomagus, H. W. J. P., Krieg, H. M., Keizer, K., Separation and Purification echnology, Vol. 25 (2001), p.407

$10.1016 / \mathrm{S} 1383-5866(01) 00069-7$ 